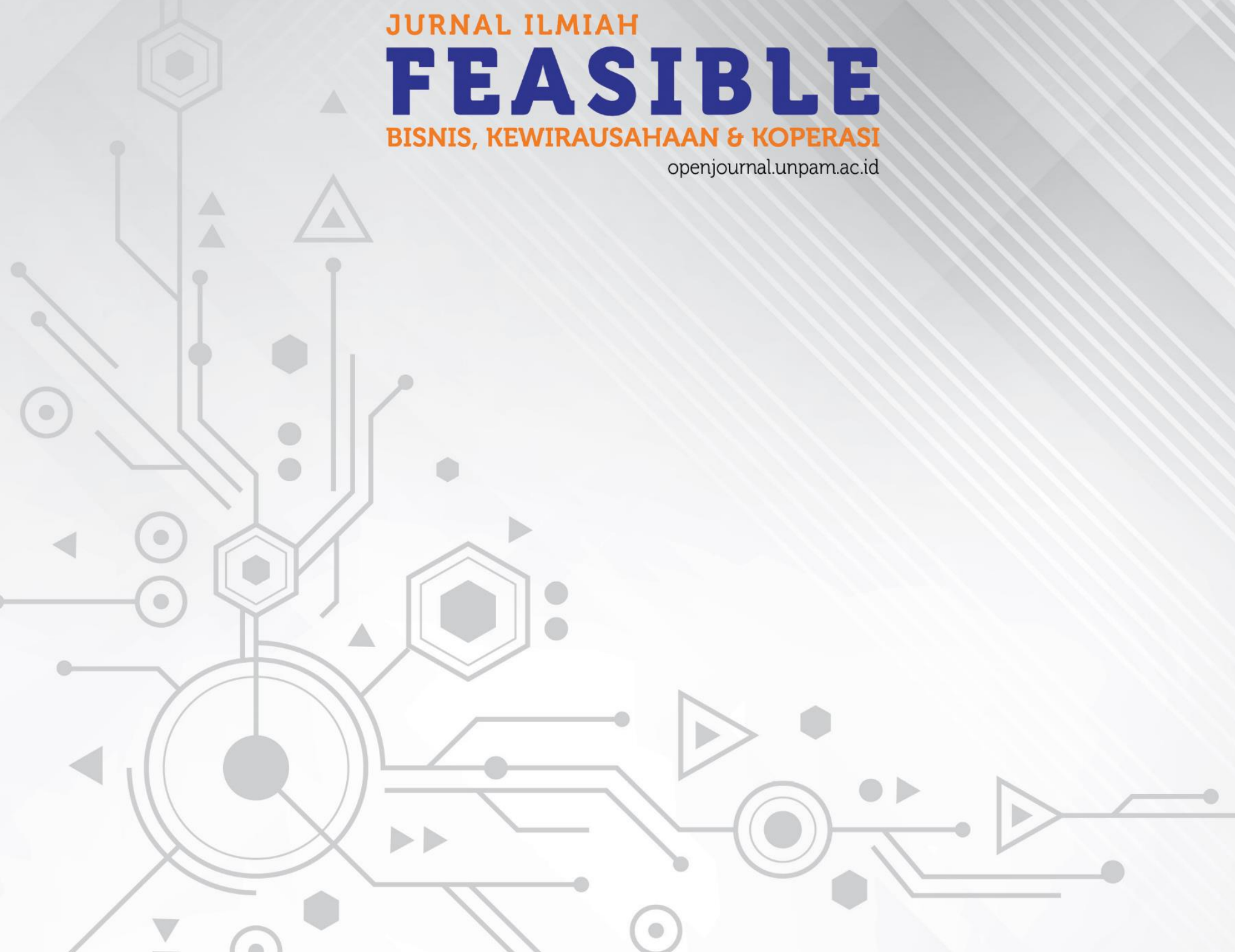




\title{
ANALISA PEMAHAMAN PENJUALAN MELALUI E-COMMERCE PADA KOPERASI PATIH SEJAHTERA MANDIRI KELURAHAN CEMPAKA PUTIH KECAMATAN CIPUTAT TIMUR TANGERANG SELATAN
}

\author{
Yayan Sudaryana', Jeni Andriani² \\ FakultasEkonomi,UniversitasPamulang \\ yayansudaryana@yahoo.com, jeni.andriani@yahoo.co.id
}

\begin{abstract}
Abstrak
Tujuan penelitian ini untuk mengetahui sejauh mana pemahaman Koperasi Patih Sejahtera Mandiri Kelurahan Cempaka Putih Kecamatan Ciputat Timur Tangerang Selatan yang memiliki anggota IKM/UKM yang aktif sejumlah 55 dengan berbagai kegiatan usaha baik sebagai produsen barang dan jasa maupun sebagai pedagang barang dan jasa mengenai penjualan melalui e-commerce. Pengumpulan data dalam penelitian ini menggunakan metode wawancara, kuesioner, observasi dan dianalisis secara deskriptif. Hasil dari penelitian ini adalah bahwa IKM/UKM anggota Koperasi Patih Sejahtera Mandiri Kelurahan Cempaka Putih Kecamatan Ciputat Timur Tangerang Selatan sangat memahami mengenai penjualan melalui e-commerce, ditunjukkan dengan pemahaman terhadap UU No. 8 tahun 1999 tentang perlindungan konsumen mencapai 91,44\%, pemahaman terhadap UU No. 7 tahun 2014 tentang perdagangan mencapai 88,22 \%, dan pemahaman terhadap UU No. 19 Tahun 2016 tentang ITE 87,75\%.
\end{abstract}

Kata Kunci : Pemahaman, Penjualan, E-Commerce

\begin{abstract}
The purpose of this study was to determine the extent of understanding of the Koperasi Patih Sejahtera Mandiri, Cempaka Putih, Ciputat Timur, South Tangerang, which has 55 active members of small and medium enterprises with various business activities both as producers of goods and services and as merchants of goods and services regarding sales through $e-$ commerce. Collecting data in this study using interviews, questionnaires, observations and analyzed descriptively. The results of this study are that the Koperasi Patih Sejahtera Mandiri, Cempaka Putih, Ciputat Timur, South Tangerang, are very understanding about sales through e-commerce, indicated by an understanding of Law No. 8 of 1999 concerning consumer protection reached $91.44 \%$, understanding of Law No. 7 of 2014 concerning trade reached $88.22 \%$, and understanding of Law No. 19 of 2016 concerning ITE 87.75\%.
\end{abstract}

Keywords: Understanding, Sales, E-Commerce 
JURNAL ILMIAH FEASIBLE: Bisnis, Kewirausahaan\&Koperasi, Vol.1.No.2 Agustus 2019: 108-114

\section{PENDAHULUAN}

\section{Latar Belakang}

Di era globalisasi ini dengan perkembangan teknologi yang begitu pesat, persaingan di dunia bisnis menjadi semakin ketat. Persaingan adalah inti dari kesuksesan atau kegagalan perusahaan. Terdapat dua sisi yang ditimbulkan oleh persaingan, yaitu sisi kesuksesan karena mendorong perusahaan-perusahaan untuk lebih dinamis dan bersaing dalam menghasilkan produk serta memberikan layanan terbaik bagi pasarnya, sehingga persaingan dianggapnya sebagai peluang yang memotivasi. Sedangkan sisi lainnya adalah kegagalan karena akan memperlemah perusahaan-perusahaan yang bersifat statis, takut akan persaingan dan tidak mampu menghasilkan produk-produk yang berkualitas, sehingga persaingan merupakan ancaman bagi perusahaannya.

Koperasi Menurut UU No. 25 Tahun 1992, adalah badan usaha yang beranggotakan orang-orang atau badan hukum koperasi, dengan melandaskan kegiatannya berdasarkan prinsip koperasi sekaligus sebagai gerakan ekonomi rakyat yang berdasar atas azas kekeluargaan. Koperasi merupakan wadah bagi pengembangan IKM/UKM dalam hal pembiayaan maupun pemasarannya, di mana koperasi digunakan sebagai tempat pemasaran produk IKM/UKM baik secara offline maupun online mengikuti perkembangan teknologi.
Berdasarkan hasil observasi dan wawancara dengan dengan Lurah dan Ketua Koperasi Patih Sejahtera Mandiri di kantor Kelurahan Cempaka Putih Kecamatan Ciputat Timur ]Tangerang Selatan, diperoleh data atau informasi bahwa Koperasi Patih Sejahtera Mandiri memiliki anggota yang aktif sejumlah 55 orang dari kurang lebih 180 IKM/UMKM dengan berbagai bidang kegiatan usaha dan dari IKM/UMKM anggota Koperasi Patih yang telah melakukan transaksi penjualan melalui e-Commerce baik dalam rangka penjualan di dalam negeri maupun ke luar negeri (ekspor).

Demikian juga diperoleh informasi bahwa permasalahan yang dihadapi IKM/UMKM Koperasi Patih Sejahtera adalah kurangnya pemahaman penjualan melalui e-commerce terutama penjualan ke luar negeri (ekspor). Berdasarkan Peraturan Menteri Perdagangan No. 13 tahun 2012 tentang Ketentuan Umum dibidang Ekspor, bahwa barang ekspor dikelompokkan ke dalam 3 kelompok barang yaitu barang bebas ekspornya, barang dibatasi ekspornya dan barang dilarang ekspornya.

Berdasarkan fenomena masalah yang terjadi tersebut peneliti tertarik untuk melakukan penelitian mengenai Analisis Pemahaman Penjualan melalui $e$ Commerce pada Koperasi Patih Sejahtera Mandiri Kelurahan Cempaka Putih Kecamatan Ciputat Timur Tangerang Selatan. 
JURNAL ILMIAH FEASIBLE: Bisnis, Kewirausahaan \& Koperasi, Vol.1.No.2 Agustus 2019: 108-114

\section{Rumusan Masalah}

Dari analisis situasi permasalahan sebagaimana diuraikan diatas, maka rumusan masalah sebagai berikut: Bagaimana pemahaman IKM/UKM anggota Koperasi Patih Sejahtera Mandiri Kelurahan Cempaka Putih Kecamatan Ciputat Tangerang Selatan tentang $e$ commerce, terkait dengan UU no. 7 Tahun 2014 tentang Perdagangan, UU No. 8 Tahun 1999 tentang Perlindungan Konsumen, UU No. 19 Tahun 2016 tentang Perubahan atas UU No. 11 Tahun 2008 tentang Informasi dan Transaksi Elektronik (ITE) dan Peraturan Menteri Perdagangan No. 13 tahun 2012 tentang Ketentuan Umum dibidang Ekspor..

\section{Kajian Literatur \\ Penjualan}

Penjualan (Nitisemito, 1998:32)) adalah "aktivitas atau bisnis menjual produk atau jasa yang dapat dilakukan melalui berbagai metode antara lain seperti penjualan langsung melalui e-commerce. Tujuan penjualan adalah mendatangkan keuntungan atau laba dari produk atau jasa yang dijual baik penjualan yang dilakukan di dalam negeri maupun ke luar negeri (ekspor)”. Sedangkan tugas manajemen penjualan adalah menganalisis faktorfaktor lingkungan yang relevan; menetapkan tujuan; memahami prosedur untuk kelancaran penjualan; dan melakukan pengawasan pelaksanaan penjualan sesuai rencana. Perbedaan antara konsep penjualan, konsep pemasaran, dan konsep perdagangan adalah Konsep penjualan memfokuskan pada penjualan (barang terjual) sedangkan konsep pemasaran memfokuskan pada kebutuhan pembeli dan konsep perdagangan mempokuskan pada kesepakatan bersama bukan pemaksaaan.

\section{e-Commerce}

"E-Commerce (perdagangan elektronik) adalah pembelian, penjulan dan pemasaran barang serta jasa melalui system elektronik" (Jony Wong 2002 :15). Pemanfaatan $e$-Commerce, telah mendorong perubahan kegiatan usaha dari hanya secara offline juga online sehingga para penjual dan pembeli tidak saling bertemu secara lang sung untuk bertransaksi. Menurut data Badan Pusat Statistik (BPS), kontribusi Usaha Mikro Kecil Menengah (UMKM) terhadap Produk Domestik Bruto (PDB) Indonesia mencapai 61,41\%, dengan jumlah UMKM hampir mencapai 60 juta. Namun, baru sekitar $8 \%$ atau sebanyak 3,79 juta pelaku UMKM yang sudah memanfaatkan Teknologi Informasi dan Komunikasi (TIK) atau bertransaksi secara online atau platform online untuk memasarkan produk/ barangnya. Bahkan roadmap pemerintah, pada 2020 transaksi e-Commerce diprediksi mencapai Rp. 1.300 Triliun.

Sebagai acuan bagi setiap pelaku usaha dalam melakukan transaksi perdagangan, baik perdagangan konvensional maupun perdagangan melalui online atau e-commerce (perdagangan elektronik), yaitu 1) UU no. 7 tahun 2014 
tentang Perdagangan, bahwa perdagangan melalui sistem elektronik adalah perdagangan yang transaksinya dilakukan melalui serangkaian perangkat dan prosedur elektronik, dimana setiap pelaku usaha wajib menyediakan data dan/atau informasi secara lengkap dan benar, paling sedikitnya memuat : a). Identitas dan legalitas pelaku usaha sebagai produsen atau distribusitor, b). Persyaratan teknis barang yang ditawarkan, c). Harga dan cara pembayaran, d) Cara penyerahan barang. dan 2). UU No. 8 Tahun 1999 tentang Perlindungan Konsumen, antara lain bahwa pelaku usaha dalam menawarkan barang dan/atau jasa yang ditujukan untuk diperdagangkan dilarang menawarkan, mempromosikan, mengiklankan atau membuat pernyataan yang tidak benar atau menyesatkan mengenai tawaran potongan harga atau hadiah menarik yang ditawarkan. Selanjutnya jika melanggar maka dipidana paling lama 5 (lima) tahun atau pidana denda Rp. 2 milyar serta 3). UU No.11 Tahun 2008 tentang Informasi dan Transaksi Elektronik (ITE) sebagaimana telah diubah oleh UU No. 19 Tahun 2016 tentang Perubahan atas UU No. 11 Tahun 2008 tentang Informasi dan Transaksi Elektronik (ITE) antara lain bahwa Setiap orang dengan sengaja, dan tanpa hak menyebarkan berita bohong dan menyesatkan yang mengakibatkan kerugian konsumen dalam transaksi elektronik, dipidana penjara paling lama 6 (enam) tahun dan/atau denda Rp. 1 (satu) Milyar.

\section{METODE}

\section{Lokasi Penelitian}

Penelitian ini dilaksanakan pada Koperasi Patih Sejahtera Mandiri Kelurahan Cempaka Putih Kecamatan Ciputat Timur Tangerang Selatan.

\section{Populasi dan sampel}

Populasi dan sampel dalam penelitian ini adalah IKM/UKM anggota Koperasi Patih Sejahtera Mandiri Kelurahan Cempaka Putih Kecamatan Ciputat Tangerang Selatan yang aktif sejumlah 55 .

\section{Metode Pengumpulan Data}

Metode pengumpulan dalam penelitian ini adalah :

\section{a. Wawancara}

Merupakan proses untuk memperoleh data dengan cara melakukan tanya jawab, dalam hal ini dilakukan dengan Bapak Iskandar Yaksimu selaku Ketua Umum Koperasi Patih Sejahtera Mandiri dan Bapak Tarmizi selaku Lurah di Kelurahan Cempaka Putih Kecamatan Ciputat Timur Tangerang Selatan.

b. Angket (Kuesioner)

Menurut Sugiyono (2016:142), "kuesioner merupakan teknik pengumpulan data yang dilakukan dengan cara memberi seperangkat pernyataan tertulis kepada responden untuk dijawabnya”. Angket ini ditujukan kepada IKM/UKM anggota Koperasi Patih Sejahtera Mandiri yang masih aktif.

c. Observasi 
JURNAL ILMIAH FEASIBLE: Bisnis, Kewirausahaan \& Koperasi, Vol.1.No.2 Agustus 2019: 108-114

Merupakan proses pengumpulan data dengan mengadakan pengamatan langsung pada objek penelitian untuk memperoleh data yang diperlukan, yang dalam hal ini dilakukan secara langsung terhadap Koperasi Patih Sejahtera Mandiri Kelurahan Cempaka Putih Kecamatan Ciputat Timur Tangerang Selatan.

\section{Metode Pengolahan Data}

Metode pengolahan data yang digunakan dalam penelitian ini adalah analisis deskriptif, yang diolah data dan disajikan dalam bentuk tulisan, tabulasi data, dan gambar yang sesuai dengan teori.

\section{HASIL dan PEMBAHASAN}

\section{Hasil}

Hasil Analisis Deskriptif jawaban responden terkait dengan pemahaman $e$ Commerce adalah sebagai berikut :

\begin{tabular}{|l|l|c|c|}
\hline \multicolumn{3}{|c|}{ Tabel 1.1. : Analisis Deskriptif Pemahaman } \\
Penjualan melalui E-Commerce
\end{tabular}

\begin{tabular}{|c|c|c|c|}
\hline No & Pertanyaan & $\mathrm{Ya}=1$ & $\begin{array}{l}\text { Tidak } \\
=0\end{array}$ \\
\hline 1 & Barang dibatasi & 55 & - \\
\hline 2 & $\begin{array}{l}\text { Barang dilarang } \\
\text { diekspor }\end{array}$ & 55 & - \\
\hline 3 & $\begin{array}{l}\text { Barang bebas di } \\
\text { ekspor }\end{array}$ & 44 & 11 \\
\hline $\mathrm{E}$ & $\begin{array}{l}\text { Pemahaman Cara } \\
\text { Penyerahan Barang } \\
\text { ekspor } \\
(\text { rata-rata / \%) }\end{array}$ & $\begin{array}{c}93,09 \\
\%\end{array}$ & $\begin{array}{c}6,91 \\
\%\end{array}$ \\
\hline 1 & EXW - Ex Works, & 55 & - \\
\hline 2 & FCA - Free Carrier & 55 & - \\
\hline 3 & $\begin{array}{l}\text { CPT - Carriage Paid } \\
\text { To CIF / Carriage and } \\
\text { Insurance Paid to }\end{array}$ & 43 & 12 \\
\hline 4 & DAT - Delivered At & 48 & 7 \\
\hline 5 & $\begin{array}{l}\text { DAP - Delivered at } \\
\text { Place }\end{array}$ & 45 & 10 \\
\hline 6 & $\begin{array}{l}\text { DDP - Delivered } \\
\text { Duty Paid }\end{array}$ & 46 & 9 \\
\hline 7 & $\begin{array}{l}\text { FAS - Free Alongside } \\
\text { Ship }\end{array}$ & 55 & - \\
\hline 8 & FOB - Free On Board & 55 & - \\
\hline 9 & $\begin{array}{l}\text { CFR - Cost and } \\
\text { Freight }\end{array}$ & 55 & - \\
\hline 10 & $\begin{array}{l}\text { CIF - Cost, Insurance } \\
\text { and Freight, }\end{array}$ & 55 & - \\
\hline $\mathrm{F}$ & $\begin{array}{l}\text { Pemahaman Jenis } \\
\text { dokumen utama } \\
\text { ekspor } \\
(\text { rata-rata / \%) }\end{array}$ & $\begin{array}{c}88,18 \\
\%\end{array}$ & $1,82 \%$ \\
\hline 1. & Sales Contract & 44 & 11 \\
\hline 2 & Packing List & 55 & - \\
\hline 3 & Commercial Invoice & 55 & - \\
\hline 4 & $\begin{array}{l}\text { Konosemen }(\mathrm{B} / \mathrm{L}, \\
\mathrm{AWB}, \mathrm{RCN}),\end{array}$ & 40 & 15 \\
\hline 5 & Asuransi Ekspor & 55 & - \\
\hline 6 & $\begin{array}{l}\text { SKA (Surat } \\
\text { Keterangan Asal). }\end{array}$ & 42 & 13 \\
\hline $\mathrm{G}$ & $\begin{array}{l}\text { Prosedur Ekspor ( } \\
\text { rata-rata / \%) }\end{array}$ & $\begin{array}{c}81,82 \\
\%\end{array}$ & $\begin{array}{c}18,18 \\
\%\end{array}$ \\
\hline $\mathrm{H}$ & $\begin{array}{l}\text { Cara Pembayaran } \\
\text { ekspor ( rata-rata / \%) }\end{array}$ & $\begin{array}{c}72,73 \\
\%\end{array}$ & $\begin{array}{c}27,27 \\
\%\end{array}$ \\
\hline
\end{tabular}

\section{Pembahasan}

Berdasarkan hasil Analisis Deskriptif atas jawaban responden terhadap pemahaman e-commerce, sebagaimana tabel 1.1 diatas, sebagai berikut menunjukkan 
bahwa tertinggi pada Pemahaman terhadap UU No. 8 tahun 1999 tentang perlindungan konsumen mencapai 91,44 \%, disusul Pemahaman terhadap UU No. 7 tahun 2014 tentang perdagangan mencapai 88,22 \%, dan pemahaman terhadap UU No. 19 Tahun 2016 tentang ITE 87,75 \%. Selanjutnya pemahaman terhadap keten-tuan barang ekspor 93,33 \% tertinggi dibandingkan dengan pemahaman ter-hadap cara penyerahan barang ekspor 93,09 \%, pemahaman jenis dokumen utama ekspor 88,18 \%,, pemahaman prosedur ekspor 81,82 \% dan pemahaman cara pembayaran ekspor 72,73\%.

Beberapa jawaban terendah yaitu pemahaman terhadap barang bebas diekspor $80 \%$, disusul pemahaman terhadap cara penyerahan barang ekspor pada DAP ( Delivered at Place ) $81,82 \%$ dan pemahaman jenis dokumen utama ekspor pada konosemen ( $\mathrm{B} / \mathrm{L}, \mathrm{AWB}, \mathrm{RCN}$ ) $81,82 \%$.

\section{SIMPULAN}

\section{Kesimpulan}

IKM/UKM anggota Koperasi Patih Sejahtera Mandiri Kelurahan Cempaka Putih Kecamatan Ciputat Timur Tangerang Selatan sangat memahami mengenai penjualan melalui e-commerce ditunjukan dengan :

1. Pemahaman terhadap UU No. 8 tahun 1999 tentang perlindungan konsumen mencapai $91,44 \%$.
2. Pemahaman terhadap UU No. 7 tahun 2014 tentang perdagangan mencapai $88,22 \%$

3. Pemahaman terhadap UU No. 19 Tahun 2016 tentang ITE $87,75 \%$.

\section{Saran}

Perlu dilakukan bimbingan teknis terutama terkait dengan materi ketentuan barang ekspor, cara penyerahan barang ekspor, jenis dokumen utama ekspor prosedur ekspor , cara pembayaran ekspor

\section{DAFTAR PUSTAKA}

Jony Wong, dalam Nitisemito 1998, Manajemen Pemasaran, Jakarta Ghali Indonesia

Porter dalam Muhardi 1998, Manajemen Pemasaran, Jakarta Ghalia Indonesia Reeve, Warren dan Duchac, dalam Nitisemito 1998, Manajemen Pemasaran, Jakarta Ghalia Indonesia Sugiyono. 2016. Metode Penelitian Pendidikan: Pendekatan Kuantitatif. Kualitatif. dan R\&D. Bandung: Alfabeta.

UU No. 25 Tahun 1992 tentang Koperasi

UU No. 7 tahun 2014 tentang Perdagangan,

UU No. 8 Tahun 1999 tentang Perlindungan Konsumen

UU No.11 Tahun 2008 tentang Informasi dan Transaksi Elektronik (ITE) sebagaimana telah diubah oleh UU No. 19 Tahun 2016 tentang Perubahan atas UU No. 11 Tahun 2008 tentang 
JURNAL ILMIAH FEASIBLE: Bisnis, Kewirausahaan \& Koperasi, Vol.1.No.2 Agustus 2019: 108-114

Informasi dan Transaksi Elektronik

(ITE)

Peraturan Menteri Perdagangan No. 13

tahun 2012 tentang Ketentuan Umum

dibidang Ekspor,

Badan Pusat Statistik (BPS), tahun 2018. 